Daniel Słapek

Università Jagellonica di Cracovia

https://doi.org/10.18778/8220-506-0.18

\title{
ILE „WŁOSKOŚCI” W TEKSTACH POLSKICH ITALIANISTÓW? UWAGI BIBLIOMETRYCZNE
}

\begin{abstract}
How much "Italianity" in the texts of Polish Italians? Bibliometric notes. The sociology of science treats scientific activity as a given system of relations and social processes. The specific goals of this meta-scientific discipline include the analysis of grant/funding policy, the bibliometric analysis of academic output, the designation of authorities in a given field, the study of conference/doctoral dissertation topics, etc. In today's academic reality, representatives of foreign language and literature studies, belonging to different schools and scientific paradigms, constitute a special group. Their research work is difficult because - in practice - they often must reconcile two scientific perspectives/traditions, and their belonging, so to speak, to different scientific paradigms makes the circle of their potential discussants quite limited. In this chapter, I attempt to carry out a bibliometric analysis of the scientific publications written by Polish Italianists in 2019, in terms of their "Italianity", i.e., belonging to the Italian academic tradition. In the general section, we will see statistics on the language and place of publication, the affiliation of the author in relation to the place of publication, and the cooperation of the authors/editors. The detailed section presents an analysis of the bibliographic references published in the journal articles in terms of the type of publications cited, their language, and their place of publication.
\end{abstract}

Keywords: bibliometrics, scientific publications, bibliographies, meta-science, academic identity, Italian studies in Poland.

Słowa klucze: analiza bibliometryczna, literatura naukowa, bibliografia, metanauka, tożsamość naukowa, italianistyka polska. 


\section{Wstęp}

Odkąd, w roku akademickim 1973/74, utworzono pierwsze w Polsce autonomiczne studia italianistyczne (Widłak 2015: 26) ${ }^{1}$, filologia włoska wypracowała już chyba stabilną pozycję na gruncie krajowej neofilologii. Dziś studia włoskie (italianistykę, filologię, język włoski) można studiować aż na 15 wydziałach ${ }^{2} \mathrm{i}$ - wbrew, zdaje się, ogólnym tendencjom obserwowanym w humanistyce - liczba ta wciąż rośnie. Jeszcze niedawno, bo w roku akademickim 2012/13, Artur Gałkowski (2014: 9) wyliczał 14 sekcji (zakładów/katedr) italianistyki $\mathrm{w}$ Polsce ${ }^{3}$, z kolei od roku 2020/21 podobne studia znajdują się w ofercie edukacyjnej kolejnej uczelni publicznej ${ }^{4}$.

Rozkwit naszej dyscypliny ${ }^{5}$ możliwy jest $\mathrm{z}$ pewnością dzięki rozwojowi italianistycznej kadry naukowej (w samym tylko roku 2019 obroniono aż 10 doktoratów wpisujących się w filologiczne studia włoskie ${ }^{6}$; czynni naukowo italianiści pracują również na uczelniach nieprowadzących pełnych studiów

1 Dla porównania, niezależna Katedra Italianistyki UW powstała w roku 1982 (Żaboklicki 2012: 10). Nauczanie języka włoskiego w Polsce ma dłuższą historię - pierwsza katedra języka i literatury włoskiej została utworzona na UJ już w roku akademickim 1806/7 -, zresztą nie tylko uniwersytecką (na ten temat zob. m.in. Jamrozik 2014; Palmarini 2015; Widłak 1991).

2 Mowa tu o wydziałach, ponieważ UW oferuje studia o profilu italianistycznym w dwóch jednostkach: na Wydziale Neofilologii i na Wydziale Lingwistyki Stosowanej. Inne uczelnie prowadzące studia italianistyczne to a) uczelnie publiczne: UAM, UKSW w Warszawie, UMK w Toruniu, Politechnika Śląska, Uniwersytety: Jagielloński, Łódzki, Pedagogiczny w Krakowie, Szczeciński, Śląski, Wrocławski; b) uczelnie niepubliczne: Ateneum - Szkoła Wyższa w Gdańsku, Uniwersytet SWPS w Warszawie, Wyższa Szkoła Filologiczna we Wrocławiu. Krótki opis wybranych jednostek znajdziemy u Marty Kaliskiej (2018: 417-420).

3 Od roku 2012/13 zaprzestano już rekrutacji na italianistykę w Wyższej Szkole Studiów Międzynarodowych $w$ Łodzi, z kolei kierunek ten utworzono na Uniwersytecie Wrocławskim i UKSW w Warszawie.

4 Italianistyka widnieje jako nowość dla kandydatów na studia Wydziału Nauk Humanistycznych KUL-u.

5 Terminu 'dyscyplina' używam jako określenia zwyczajowego, które odnosi się tutaj do italianistyki; w myśl rozporządzenia MNiSW „w sprawie dziedzin nauki i dyscyplin naukowych oraz dyscyplin artystycznych" (Dz.U. 2018 poz. 1818) badania italianistyczne wpisują się $\mathrm{w}$ następujące dyscypliny: językoznawstwo, literaturoznawstwo, nauki o kulturze i religii.

6 Anna Dyda (UJ), Iga Figarska-Bączyk (UW), Joanna Jarczyńska (UW), Dorota Kozakiewicz (UW), Małgorzata Lewandowska (UW), Lucia Pascale (UW), Barbara Rejmak (UW), Dorota Sieroń (UJ), Ewelina Walendziak-Genco (UW), Ryszard Wyleciol (UŚ). 
italianistycznych ${ }^{7}$ ), za którym idzie wzmożona działalność naukowa i jej namacalne efekty w postaci publikacji naukowych. To właśnie efektom tej pracy warto - jak sądzę - przyjrzeć się z punktu widzenia bibliometrii, tj. poprzez zastosowanie metod statystycznych, których celem jest „charakterystyka ilościowa [...] struktury (np. formalnej, tematycznej, językowej) [piśmiennictwa naukowego] oraz określenie tendencji rozwojowych, z praktycznego puntu widzenia" (Stefaniak 1998: 198). Badania takie można wpisać w ramy szeroko rozumianej metanauki ${ }^{8}$.

W środowisku akademickim bibliometria może kojarzyć się negatywne, bo też narzędzia, którymi operuje (wskaźniki, indeksy cytowań itd.), wykorzystywane są do ewaluacji jednostek naukowych ${ }^{9}$, ale i - w praktyce - do indywidualnej oceny pracowników naukowych zarówno na poziomie danej jednostki ${ }^{10}$, jak i krajowym ${ }^{11}$. W mojej pracy nie idzie jednak o ocenę, a o wykorzystanie

7 Są to m.in. UG, UMCS, Uniwersytet Papieski JPII w Krakowie.

8 Por. definicję bibliometrii Aidy Martinez-Gómez (2015: 206): „Making science out of science - or more precisely, meta-science out of scholarly output - is the main goal of bibliometrics"; oraz definicję Głównego Urzędu Statystycznego (GUS 1999): „Zastosowanie metod matematycznych i statystycznych do literatury naukowej (a także patentów i innych środków przekazywania informacji). Pozwala na ocenę wielkości 'produkcji naukowej', opierając się na założeniu, że istotą działalności naukowej (badawczej i rozwojowej, B+R) jest produkcja 'wiedzy' (knowledge), znajdująca swoje odzwierciedlenie w literaturze naukowej”; na temat zależności terminów 'bibliometria', 'naukometria' i 'infometria', zob. również Hood i Wilson (2001).

9 Istotnie, zgodnie z rozporządzeniem polskiego $\mathrm{MNiSW}$ „w sprawie sporządzania wykazów wydawnictw monografii naukowych oraz czasopism naukowych i recenzowanych materiałów z konferencji międzynarodowych" (Dz.U. 2018 poz. 2152), sam wykaz w zasadniczej części opiera się na czasopismach indeksowanych w międzynarodowych bazach Scopus i Web of Science ( $\$ 6.1$ ), których punktacja uzależniona została od wskazanych w rozporządzeniu wskaźników cytowań (\$ 8.1).

10 W lutym $2020 \mathrm{r}$. Zespół do spraw monitorowania wdrażania reformy szkolnictwa wyższego i nauki przedstawił "uwagi dotyczące statutów uczelni i oceny indywidualnej nauczycieli akademickich", w których podobne działania jednoznacznie uznane są za niewłaściwe: „[...] ocena indywidualna pracownika w zakresie zadań badawczych i nauki nie powinna być zawężona do wyników naukowych uzyskanych w zakresie deklarowanej przez pracownika dyscypliny badawczej [...]. Ocena ta nie może zależeć od punktów wygenerowanych przez dorobek pracownika w ramach oceny dyscyplin naukowych uprawianych w danej uczelni” (Żylicz 2020).

11 Przykładem niech będzie system ZSUN/OSF przeznaczony m.in. do rejestrowania i obsługi wniosków grantowych MNiSW: pracom zgłaszanym w ramach oceny dorobku naukowego wnioskodawcy automatycznie przypisywana jest aktualnie obowiązująca punktacja, która w dużej mierze jest pochodną indeksów cytowań (por. przypis nr 9). Oceny na podstawie indeksu cytowań budzą wiele kontrowersji, nie tylko w Polsce (por. Drabek 2012: 1); z gruntu włoskiego przytoczę dla przykładu 
bibliometrii do ukazania pewnych tendencji właściwych polskiej italianistyce, zrozumienie dynamiki naszych badań naukowych i próbę omówienia tytułowego problemu „włoskości” tekstów polskich italianistów czy też - innymi słowy - tożsamości naukowej neofilologa-italianisty ${ }^{12}$. Zgodnie z założeniami humanistyki afirmatywnej, idzie tu również „o podkreślenie aspektu przyszłościowego projektu i skupienie się nie tyle na krytyce istniejącego systemu, ale biorąc za punkt wyjścia [...] efekty, próba budowania lepszego" (Domańska 2017: 42).

Przedstawione dalej rozważania to nie tylko analiza tekstów naukowych pisanych w ramach italianistyki polskiej, ale także kierowane do koleżanek i kolegów italianistów zaproszenie do refleksji nad własną pracą naukową.

\section{Bibliografia naukowa italianistyki polskiej}

Analizy bibliometryczne prowadzone są na poziomie macro (tj. w skali kraju/regionu), meso (badania obejmujące instytucje, np. uniwersytety, wydziały) i micro (katedry, zakłady, grupy badawcze czy nawet indywidualnych badaczy) (por. np. van Raan 2003: 21). Przedstawiona dalej analiza dorobku polskiej italianistyki obejmuje zatem najszerszy zakres bibliometryczny, choć ograniczona została do określonych ram czasowych. Można też wyobrazić sobie badania na jeszcze większą skalę, obejmujące np. wszystkie światowe czasopisma italianistyczne. Rzecz jasna, należałoby w tym celu opracować najpierw odpowiednie zestawienia, bibliografie czy nawet obszerne bazy danych (zresztą na każdym poziomie badań).

W ramach studiów włoskich pojawiło się już kilka prac przeglądowych, np. - dla italianistyki macedońskiej - Gli studi contrastivi dell'italianistica macedone: sviluppi e recenti prospettive (Ivanovska-Naskova 2019) czy - dla italianistyki krajów skandynawskich - specjalny numer Studi Italiani di Linguistica Teorica e Applicata (anno XLVII - fascicolo 1/2018) pt. „La linguistica italiana nei Paesi nordici” (przedstawiający, odpowiednio dla pięciu krajów, „krótkie panoramy" studiów włoskich; zob. Korzen 2018; oba przykłady to jednak studia przeglądowe a nie stricte bibliometryczne). Do dyspozycji badaczy jest również portal Italinemo.it, którego celem jest - jak czytamy na stronie głównej - „Analisi, Schedatura, indicizzazione delle riviste di Italianistica pubblicate nel mondo a partire dal 2000”. Portal udostępnia abstrakty artykułów oraz umożliwia zaawansowane wyszukiwanie hasłowe w tekstach, które gromadzi (choć

wymowny tytuł monografii Alberta Bacciniego, Valutare la ricerca scientifica. Uso e abuso degli indicatori bibliometrici (2010).

12 Por. rozważania na temat tożsamości neofilologa-romanisty autorstwa Elżbiety Biardzkiej (2018). 
bardzo bogata, jest to jednak niepełna baza danych, a umieszczenie i regularne indeksowanie nowego tytułu jest usługą płatną).

$\mathrm{Z}$ kolei w badaniu krajowego dorobku naukowego źródłem danych może być „Polska Kronika Italianistyczna”, która ukazuje się dorocznie na łamach czasopisma Italica Wratislaviensia (w tomie 6/2015 opublikowano pierwszą kronikę, za rok 2014) i zawiera m.in. spis publikacji koleżanek i kolegów italianistów. W pierwszych pięciu kronikach redaktorzy ograniczyli się przede wszystkim do monografii naukowych, w roku 2020 (tom 11/1) po raz pierwszy ukazała się pełna bibliografia prac naukowych italianistyki polskiej - Bibliografia dell'italianistica polacca 2019 (w skrócie BIP19) - opracowana w celu promocji dorobku naukowego polskich italianistów w kraju i za granicą. Jak czytamy we wstępie, „spero che una simile bibliografia possa rendere le nostre ricerche più complete e ricche di fonti anche meno conosciute al di fuori dell'ambiente accademico polacco" (Słapek 2020: 235). BIP19 stanowi korpus dla przedstawionej dalej analizy bibliometrycznej.

\subsection{Bibliografia za rok 2019}

Zestawienie opublikowane $\mathrm{w}$ ostatnim tomie wrocławskich Italików zawiera prace naukowe, których data publikacji przytoczona na stronie redakcyjnej to rok 2019. Nie uwzględniono tekstów, które fizycznie trafily do obiegu w 2019 r., ale ich oficjalna data wydania jest wcześniejsza; au contraire, ujęte zostały publikacje, które ukazały się w roku 2020 z datą 2019 (z uwagi na okresowy wymiar ewaluacji jednostek naukowych, wydawniczą praktykę sygnowania publikacji datą wcześniejszą - w szczególności opóźnienia w druku monografii i czasopism naukowych - należałoby ocenić negatywnie; łatwo przewidzieć sytuacje problematyczne, kiedy autor nie doczekuje się tekstu przed zakończeniem okresu objętego oceną, zaś w kolejnym terminie nie zostanie on wzięty pod uwagę, właśnie ze względu na wsteczną datę wydania).

Autorzy prac to pracownicy zakładów/katedr/sekcji italianistyki działających na polskich uczelniach, a także inni (neo)filolodzy o zainteresowaniach italianistycznych. BIP19 zawiera ponadto teksty wydane w zbiorach o tematyce italianistycznej, których autorzy przynależą do siostrzanych, by tak rzecz, dyscyplin humanistycznych (antropologii, historii, teorii sztuki etc.; zob. np. Maślanka-Soro i Pifko-Wadowska 2019; Miziołek, Cincotta i Rejmak 2019; Wojtkowska-Maksymik 2019; zgodnie z ty tułem niniejszego rozdziału, w przedstawionych dalej statystykach ze zbiorów tych biorę pod uwagę tylko prace autorstwa italianistó $\left.{ }^{13}\right)$. Teksty poruszają szeroko rozumiane tematy włoskie

13 Selekcja na potrzeby BIP19 była pod tym względem łagodniejsza, dzięki czemu Italica Wratislaviensia promują większą liczbę polskich publikacji o tematyce włoskiej/włosko-polskiej. 
(język, literatura, historia, polsko-włoskie związki kulturowe, studia kontrastywne itp.), a także problemy literaturoznawstwa i językoznawstwa ogólnego/ teoretycznego.

\subsection{Dane ogólne}

BIP19 zawiera 166 pozycji naukowych ${ }^{14}$, w tym 7 monografii autorskich, 8 redakcji monografii zbiorowych, 7 redakcji tematycznych numerów czasopism, 5 edycji tekstów źródłowych, a także 77 artykułów w czasopismach, 64 rozdziały w monografiach tematycznych, 14 rozdziałów w materiałach pokonferencyjnych (gdzie w tytule zbioru lub na stronie redakcyjnej pojawia się adnotacja "atti del convegno”) i 6 artykułów recenzyjnych. Warto zauważyć, że redagowane tomy zbiorowe, numery czasopism, a także rozdziały w monografiach wydanych poza granicami kraju są w dużej mierze owocem konferencji naukowych ${ }^{15}$, o czym często - choć nie zawsze - informują noty wstępne redaktorów (podobne decyzje redakcyjne są zrozumiałe, biorąc pod uwagę aktualną politykę naukową, która zdaje się nie doceniać tego rodzaju publikacji).

Wykres 1 obrazuje liczbę publikacji oraz ich proporcje ze względu na rodzaj. Część wewnętrzna przedstawia dane oficjalne, część zewnętrzna uwzględnia rzeczywisty charakter publikacji (jeśli zatem artykuł ukazał się w pokonferencyjnym numerze czasopisma lub $\mathrm{w}$ tego typu monografii wieloautorskiej, przedstawiony jest jako publikacja w materiałach konferencyjnych).

14 Biorę pod uwagę wylącznie teksty recenzowane, zgodnie $\mathrm{z}$ definicją artykułu naukowego (zob. Rozporządzenie MNiSW z dnia 22 lutego 2019 r. w sprawie ewaluacji jakości działalności naukowej; Dz.U. 2019 poz. 392; \9.1); nie uwzględniam ponadto angielskich tłumaczeń artykułów wydanych w pierwotnej wersji po polsku ( $w$ analizie bibliometrycznej ujęte powinny zostać wersje pierwotne, tj. - w tym przypadku - artykuły z roku 2018, a zatem nie wpisujące się w przedstawione tu rozważania) oraz komunikatów naukowych i artykułów publikowanych w sekcji mini$\mathrm{ma}, \mathrm{tj}$. nieopatrzonych końcową bibliografią naukową.

15 Dane konferencji podaję w bibliografii końcowej przy odpowiednich redakcjach: 1) monografie wieloautorskie: Balducci (2019), Della Corte, Masi i Ślarzyńska (2019), Maślanka-Soro i Pifko-Wadowska (2019), Prola i Rosatti (2019b), Rella, Sánchez i Cerrato (2019), Tylusińska-Kowalska, Lipszyc i Cilloni-Gaździńska (2019); 2) czasopisma: Italica Wratislaviensa, 10/1 (Ivanovska-Naskova i Stapek 2019; teksty w części Varia nie pochodzą z konferencji), Italica Wratislaviensa, 10/2 (Gurgul, Surma-Gawłowska i Megale 2019), Kwartalnik Neofilologiczny, 66/2 (Jamrozik i Prola 2019), Nuova corrente. Rivista di letteratura e filosofia, 163 (Baldacci, Porczyk i Skocki 2019). 

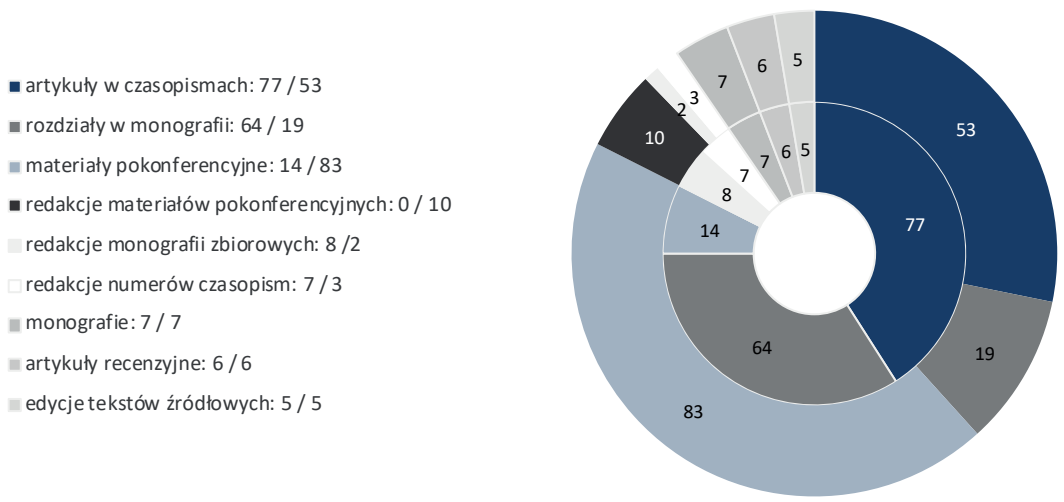

Wykres 1. Rodzaje publikacji

Źródło: opracowanie własne.

W analizie ogólnej wezmę pod uwagę 1) język, w którym zredagowany został dany tekst: włoski (IT), polski (PL), inne ${ }^{16}$; 2) miejsce publikacji: Włochy, Polska, inne; 3 ) ewentualną współpracę autorską: teksty jednego autora/redaktora (IND) i teksty napisane/zredagowane we wspólpracy (WSP); oraz - wyłącznie dla tekstów wydanych w Polsce - 4) afiliację: wewnętrzną (WEW), jeśli tekst został wydany przez jednostkę, przy której jest afiliowany, zewnętrzną (ZEWN), jeśli tekst wydała inna instytucja, i lokalną (LOK), jeśli tekst wydała instytucja mająca siedzibę w miejscowości, w którym znajduje się jednostka afiliacji autora (ponieważ wszyscy autorzy mają polskie afiliacje, teksty opublikowane poza granicami kraju z założenia wydane są przez jednostki, przy których autorzy nie są afiliowani).

W przypadku monografii autorskich (w skrócie MA) i zbiorów redagowanych - monografii wieloautorskich (MW), redakcji czasopism (RC) - językiem wiodącym jest włoski, przy czym teksty w większości opublikowane zostały przez wydawnictwa krajowe (tylko jedna monografia autorska ukazała się w Neapolu; zob. Porczyk 2019). Na tle innych kategorii zwracają uwagę monografie redagowane, ponieważ w dużej mierze zostały stworzone we wspólpracy i opublikowane poza afiliacją redaktorów (ponadto 3 zbiory wydane zostały we Włoszech). Szczegółowe dane przedstawia Wykres 2.

16 W kategorii „inne” znajdują się również monografie wieloautorskie oraz czasopisma redagowane w kilku językach. 


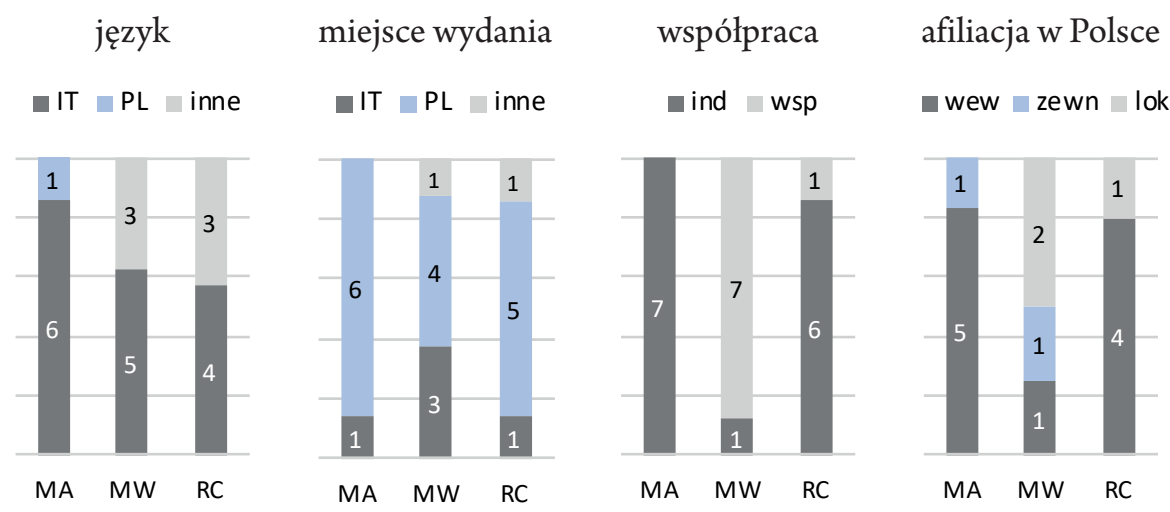

Wykres 2. Dane ogólne dot. monografii autorskich i zbiorów redagowanych

Źródło: opracowanie własne.

W przypadku tekstów „krótkich”, tj. artykułów w czasopiśmie (ART), rozdziałów w monografii (ROZ) i materiałów pokonferencyjnych (KONF), - podobnie - przeważają publikacje w języku włoskim (łącznie 76\%), opublikowane w Polsce (54\%; we Włoszech - 27\%). Wzrasta liczba publikacji wydanych w Polsce poza afiliacją autora, przede wszystkim w przypadku artykulów w czasopismach. Szczegółowe dane przedstawia Wykres 3 (afiliacja w Polsce przy materiałach pokonferencyjnych pozostaje pusta, ponieważ wszystkie oficjalnie deklarowane „atti del convegno” zostały wydane za granicą).

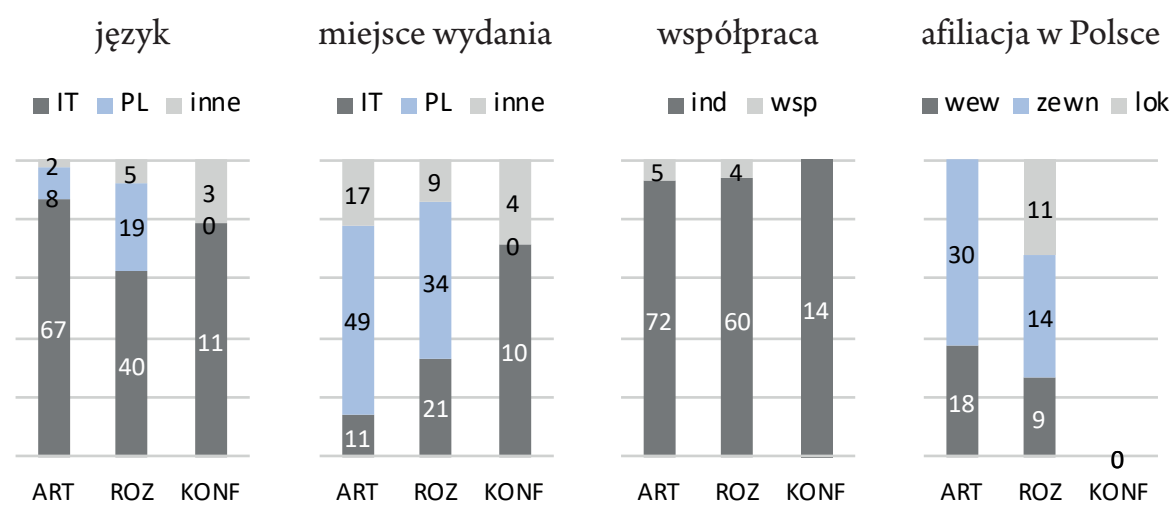

Wykres 3. Dane ogólne dot. artykułów, rozdziałów i materiałów pokonferencyjnych Źródło: opracowanie własne. 
Trudno jest wyznaczyć najczęściej wybierane wśród italianistów czasopisma naukowe. Wprawdzie kilka tytułów opublikowało znaczną część omawianych artykułów, bo aż 54\% - Kwartalnik Neofilologiczny (14), Italica Wratislaviensia (9), Nuova corrente (7), Rivista di Studi Italiani (9) -, jednak są to w większości publikacje pokonferencyjne (RSI nie jest publikacją pokonferencyjną, przy czym - choć jest to tytuł zagraniczny - redagowany jest przez ośrodek warszawski). W innych czasopismach nasze artykuły pojawiały się sporadycznie (1/2 teksty); wyjątkiem są Neophilologica, które opublikowały 5 artykułów italianistycznych, z czego 4 teksty autorów nieafiliowanych przy śląskim ośrodku akademickim (do wyznaczenia „przodujących” w italianistyce czasopism bardziej miarodajne byłyby analizy wieloletnie). Szczegółowe dane obrazuje Tabela 1, w której przedstawiono łączną liczbę opublikowanych przez dane czasopismo tekstów (n1), od której - ponadto - odjęte zostały teksty autorów afiliowanych przy instytucji wydającej dany tytuł (lub należących do komitetu redakcyjnego/naukowego czasopisma) oraz teksty powstałe w wyniku konferencji naukowej (n2).

Tabela 1. Czasopisma, w których ukazały się artykuły polskich italianistów (2019 r.)

\begin{tabular}{|c|l|c|c|}
\hline Kraj & \multicolumn{1}{|c|}{ Tytul } & \multicolumn{1}{|c|}{ n1 } & n2 \\
\hline 1 & \multicolumn{1}{|c|}{2} & 3 & 4 \\
\hline PL & Acta Philologica & 1 & 1 \\
\hline & $\begin{array}{l}\text { Annales Universitatis Mariae Curie-Skłodowska, sectio FF } \\
\text { - Philologiae }\end{array}$ & 1 & 1 \\
\hline & $\begin{array}{l}\text { Annales Universitatis Paedagogicae Cracoviensis. Studia } \\
\text { Historicolitteraria }\end{array}$ & 2 & 1 \\
\hline & Fabbrica Litterarum Polono-Italica & 3 & 0 \\
\hline & Italica Wratislaviensia & 9 & 1 \\
\hline & Kwartalnik Neofilologiczny & 14 & 2 \\
\hline & Linguistica Silesiana & 2 & 0 \\
\hline & Neophilologica & 5 & 4 \\
\hline & Polilog. Studia Neofilologiczne & 1 & 1 \\
\hline & Prace i Studia Geograficzne & 1 & 1 \\
\hline & Roczniki Humanistyczne & 1 & 0 \\
\hline & Romanica Cracoviensia & 2 & 1 \\
\hline
\end{tabular}


Tab. 1 (cd.)

\begin{tabular}{|c|c|c|c|}
\hline 1 & 2 & 3 & 4 \\
\hline \multirow[t]{5}{*}{ PL } & Studia Europea Gnesnensia & 1 & 1 \\
\hline & Studia Neofilologiczne & 1 & 1 \\
\hline & Terminus & 1 & 0 \\
\hline & Toruńskie Studia Polsko-Włoskie & 4 & 3 \\
\hline & $=$ & 44 & 15 \\
\hline \multirow[t]{6}{*}{ IT } & Eikasmos. Quaderni Bolognesi di Filologia Classica & 1 & 1 \\
\hline & Italiano LinguaDue & 1 & 1 \\
\hline & Nuova corrente. Rivista di letteratura e filosofia & 7 & 0 \\
\hline & Rassegna Italiana di Linguistica Applicata & 1 & 1 \\
\hline & Rivista Italiana di Onomastia & 1 & 0 \\
\hline & $=$ & 11 & 3 \\
\hline \multirow[t]{9}{*}{ Inne } & Bergen Language and Linguistic Studies (N) & 1 & 0 \\
\hline & Cuadernos de Filología Italiana (ES) & 1 & 1 \\
\hline & Études romanes de Brno (CZ) & 1 & 1 \\
\hline & Italian Quarterly (USA) & 2 & 2 \\
\hline & Italica Belgradensia (SRB) & 1 & 1 \\
\hline & Mnemosyne, o la costruzione del senso (B) & 1 & 1 \\
\hline & Rivista di Studi Italiani (CA) & 9 & 0 \\
\hline & Tenzone (ES) & 1 & 1 \\
\hline & $=$ & 17 & 7 \\
\hline
\end{tabular}

Źródło: opracowanie własne.

Recenzje naukowe zostały opublikowane odpowiednio a) we Włoszech ( 1 tekst; jest to jedyna recenzja promująca za granicą dorobek polskiej italianistyki; zob. Miszalska 2019); b) w Polsce (2 teksty, z których jeden promuje włoskie czasopismo naukowe; zob. Gałkowski 2019b); c) w innych krajach (3 teksty). 


\subsection{Analiza bibliografii końcowych (cytowań)}

Ze względu na dostępność wymienionych w bibliografii tekstów, w dalszej części pracy skupię się na artykułach opublikowanych w czasopismach naukowych. W dużej mierze są to teksty wydane w systemie open access (co zresztą przemawia na korzyść tego typu publikacji z punktu widzenia interesu autora i promocji jego badań) ${ }^{17}$. Przypuszczać można, że przegląd prac wydanych jako rozdziały $w$ monografiach/materiałach pokonferencyjnych autorstwa tych samych autorów dałby podobne wyniki liczbowe. Analizie poddane zostały, zatem, bibliografie końcowe 76 artykułów ${ }^{18}$, w których sprawdzono: ogólną liczbę przytoczonych pozycji naukowych (bez autocytowań), z podziałem na 1) język publikacji: a) włoski, b) polski, c) inne; 2) miejsce publikacji: a) wydawnictwo włoskie, b) wydawnictwo polskie, c) inne; oraz - co być może wykracza poza granice wytyczone w tytule, jednak daje ciekawy obraz bibliometryczny - 3) typ publikacji: a) monografie, b) rozdziały w monografiach/materiałach pokonferencyjnych, c) artykuly w czasopismach, d) inne publikacje naukowe (np. słowniki, encyklopedie, hasła słownikowe, niepublikowane prace doktorskie, przedmowy i posłowia krytyczne). Zobaczymy ponadto tytuły czasopism naukowych, w których cytowane pozycje się ukazały, a także liczbę odwołań do tekstów polskich italianistów.

W bibliografiach nie liczę treści nienaukowych, takich jak teksty źródłowe, dzieła literackie, scenariusze, które są korpusem badawczym, artykuły prasowe, nienaukowe portale/strony internetowe, słowniki językowe (jedno-, dwuczy wielojęzyczne). Rygor naukowy nakazywałby takie pozycje umieszczać w odrębnej części bibliografii. Niestety, w BIP19 nie brakuje prac, których bibliografie końcowe, po odrzuceniu treści naukowych, pozostają bardzo ograniczone ${ }^{19}$.

Teksty cytowane w artykułach naukowych polskich italianistów to, w przypadku języka i miejsca publikacji, w znacznej większości pozycje włoskie: uśredniając, a) język włoski - 58\%, język polski - 22\%, inne - 20\%; b) wydawnictwa

17 Chciałbym tym miejscu podziękować wszystkim Autorom, którzy udostępnili mi teksty niepublikowane w Open Journal System lub innych systemach otwartego dostępu do publikacji.

18 W wyliczeniach nie uwzględniam tekstów, o których mowa w przypisie nr 14. Nie liczę ponadto pozycji wykazanych w bogatej bibliografii końcowej tekstu Development of International Works on Onomastic Terminology ... (Gałkowski 2019a; bibliografia zawiera 13 monografii, 26 rozdziałów, 6 encyklopedii/słowników, 36 artykułów, które ukazały się w 16 czasopismach naukowych, w tym 14 zagranicznych, oraz 6 autocytowań), ponieważ jest to artykuł przeglądowy, tj. pozycje wymienione w bibliografii w dużej mierze stanowią korpus badawczy Autora.

19 Warto w tym miejscu przypomnieć, że wiele czasopism naukowych w formularzach dla recenzenta - style sheet for reviewers - uwzględnia również ocenę przytoczonej przez autora bibliografii. 
włoskie $-55 \%$, polskie $-22 \%$, inne $-23 \%$. Część artykułów osiąga w tych kategoriach nawet maksymalną wartość dla publikacji włoskich (w 16 tekstach wszystkie cytowania pochodzą ze źródeł włoskojęzycznych, przy czym w tekstach tych łączna liczba przytaczanych publikacji jest z reguly ograniczona, ponieważ tylko 6 bibliografii przekracza w sumie 10 pozycji). Szczegółowe dane dotyczące języka przedstawia Wykres 4: diagram liniowy określa liczbę cytowanych publikacji (wartości procentowe) dla każdego z 76 artykulów ${ }^{20}$, wykres kołowy przedstawia uśrednione dane procentowe omówione wyżej (pomijam wykres dotyczący miejsca wydania publikacji, ponieważ przebieg linii łamanej jest w nim prawie identyczny; na zmianę ma wpływ niewielka liczba tekstów zredagowanych po włosku i wydanych poza granicami Włoch).

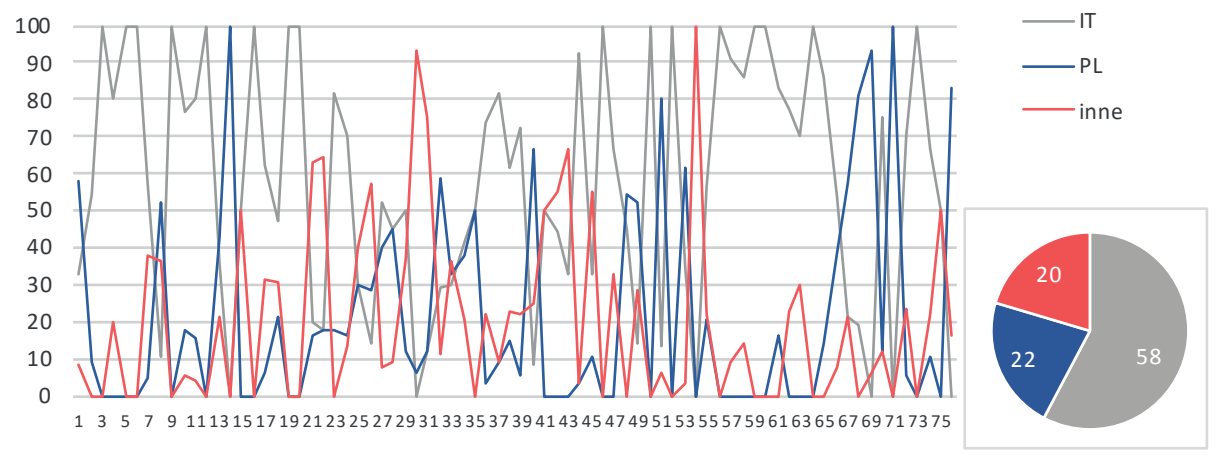

Wykres 4. Język cytowanych publikacji

Źródło: opracowanie własne.

W bibliografiach końcowych najchętniej przytaczane są pełne monografie naukowe (stanowią one średnio $61 \%$ wykazanych pozycji), na drugim miejscu plasują się rozdziały w monografiach wieloautorskich (17\%), z kolei artykuły w czasopismach są źródłami cytowanymi najrzadziej - średnio 14\% (nie licząc źródeł pomocniczych, takich jak encyklopedie/słowniki, wykazanych w kategorii ,inne”, sięgającej 8\%). Zauważalna jest więc pewna korelacja między rodzajem naszych publikacji a typem tekstów, które cytujemy: w obu przypadkach wartość liczbowa czasopism naukowych jest najniższa ${ }^{21}$. Szczegółowe

20 Artykuły uporządkowane zostały alfabetycznie, według nazwiska autora.

21 Dane te można zinterpretować również inaczej: skoro autorzy nie cytują artykułów publikowanych w prestiżowych, międzynarodowych czasopismach, to w praktyce nie poznają również norm wydawniczych takich czasopism (organizacja tekstu, kryteria, według których teksty oceniane są przez recenzentów itp.), zatem trudniej im przebić się na międzynarodowy rynek wydawniczy. 
dane pokazuje Wykres 5. Jak wyżej, diagram liniowy określa liczbę cytowanych publikacji (wartości procentowe) dla każdego analizowanego artykułu (widać tu wyraźnie przewagę monografii), wykres kołowy przedstawia uśrednione wartości procentowe.

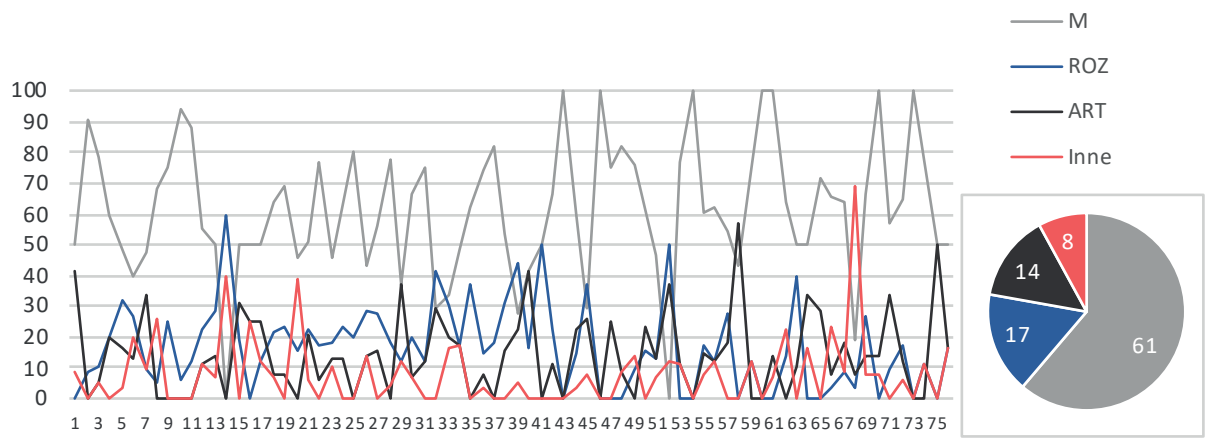

Wykres 5. Rodzaj cytowanych publikacji

Źródło: opracowanie własne.

Na podstawie danych z roku 2019 nie da się wyznaczyć czasopism, które byłyby preferowanym źródłem cytowanych prac naukowych. Zdecydowana większość tytułów przytoczona została tylko raz (117 na 129), 10 tytułów pojawia się dwukrotnie, tylko 2 tytuły cytowane są $\mathrm{w}$ trzech analizowanych tekstach $^{22}$. Tytuly zostały podzielone na kraj pochodzenia: 35 czasopism pochodzi z Polski (26\%), 43 z Włoch (33\%) i - najwięcej - 51 z innych krajów (41\%; w tym 19 ze Stanów Zjednoczonych, 9 z Francji i 6 z Wielkiej Brytanii). Pełną listę przytoczonych czasopism przedstawia Tabela 2 (w części poświęconej czasopismom wydanym w krajach innych niż Polska i Włochy, po danym tytule, $\mathrm{w}$ nawiasie, podaję miejsce publikacji; pogrubieniem zaznaczam ponadto czasopisma stricte italianistyczne).

Tabela 2. Czasopisma cytowane w artykułach polskich italianistów (2019 r.)

\begin{tabular}{|c|c|}
\hline Kraj & \multicolumn{1}{|c|}{ Tytul } \\
\hline 1 & 2 \\
\hline PL & $\begin{array}{l}\text { [33 tytuly:] Annales Universitatis Mariae Curie-Skłodowska, sectio I } \\
\text { (Philosophia-Sociologia); Annales Universitatis Mariae Curie-Skłodowska. } \\
\text { Sectio F, Nauki Filozoficzne i Humanistyczne; Annales Universitatis } \\
\text { Paedagogicae Cracoviensis. Studia Historicolitteraria; Biuletyn PTJ; }\end{array}$ \\
\hline
\end{tabular}

22 Są to włoskie Il Verri i krajowe Polonica. 
Tab. 2 (cd.)

\begin{tabular}{|c|c|}
\hline 1 & 2 \\
\hline PL & $\begin{array}{l}\text { Cognitive Studies; Czytanie literatury; Etnografia Polska; Filologia Polska. Acta } \\
\text { Universitatis Nicolai Copernici; Forum Artis Rhetoricae; Język polski ; Języki } \\
\text { obce; Kronos; Kultura i edukacja; Kultura popularna; Linguistica Copernicana; } \\
\text { LingVaria; Nowa Krytyka; Onomastica; Pamiętnik Literacki (x2); Panoptikum; } \\
\text { Polonica (x3); Poradnik językowy (x2); Postscriptum Polonistyczne; } \\
\text { Poznańskie Studia Polonistyczne. Seria Literacka; Prace Filologiczne; Prace } \\
\text { historyczne; Przegląd filozoficzno-literacki; Przestrzenie teorii; Rocznik } \\
\text { krakowski; Romanica.doc; Studia Literaria Universitatis Iagellonica } \\
\text { Cracoviensis; Studia Romanica Posnaniensia; Teka Komisji Architektury, } \\
\text { Urbanistyki i Studiów Krajobrazowych; Teksty drugie (x2); Vox patrium }\end{array}$ \\
\hline IT & $\begin{array}{l}\text { [42 tytuły: ] Antarès; Archivio d'Annunzio; Archivio per l’Antropologia } \\
\text { e l'Etnologia; Atti della Fondazione "Giorgio Ronchi”; Belfagor; Between; } \\
\text { Bollettino di storia delle scienze matematiche (x2); Critica letteraria; } \\
\text { Contemporanea; Drammaturgia; Eiris; Elephant \& Castle; Europa } \\
\text { Orientalis; Il Contesto; Il ragguaglio librario; Il Verri (x3); Italianistica; } \\
\text { Italiano e oltre; La lingua italiana; Lares; Lettere italiane; Letture Classensi; } \\
\text { LiBeR; L'immaginazione; Lingua; Lingue antiche e moderne; Medea; Otto/ } \\
\text { Novecento (x2); Poetiche; Quaderni del CeSLiC; Quaderni di semantica; } \\
\text { Quaderni storici; Quaderni; Rassegna italiana di linguistica applicata; } \\
\text { RILUNE; Rivista di filosofia scientifica; Scienza e Politica; Studi Danteschi; } \\
\text { Studi di filologia italiana; Studi di grammatica italiana (x2); Synergie Italie; } \\
\text { Teatro e Storia; Ticontre. Teoria Testo Traduzione }\end{array}$ \\
\hline Inne & $\begin{array}{l}\text { [51 tytułów:] American Quarterly (USA); Annali d'Italianistica } \\
\text { (USA); Annals of the Academy of Political and Social Science (USA); } \\
\text { Anthropological linguistics (USA); Bulletin de la Société de Linguistique } \\
\text { (FR); Cahiers Chronos (NL); Caietele Echinox (RU) (x2); Canadian } \\
\text { Modern Language Review (CA); Dante Sudies (USA); Ecozon@ (ES); } \\
\text { Educational Researcher (USA); English Language Teaching (UK); } \\
\text { Forum Italicum (USA) (x2); Incontri (NL); Information Technology } \\
\text { \& People (UK); Italica (USA) (x2); Italies (FR); Izviestiâ Volgogradskogo } \\
\text { gosudarstvennogo pedagogičeskogo universiteta. Filologičeskije nauki (RU); } \\
\text { Journal of French Language Studies (UK); Journal of the American Society } \\
\text { for Information Science and Technology (USA); Langages (FR); Language } \\
\text { (USA); Language and Cognitive Processes (UK); Le français dans le monde } \\
\text { (FR); Médiévales (FR); Modern Fiction Studies (USA); Modern Language } \\
\text { Notes (USA); Narrativa (FR); New German Critique (USA); October } \\
\text { (USA); Palimpsestes (FR); Poetics Today (USA); Poétique (FR); Ramus } \\
\text { (UK); Revista de italianística (BR); Revista de Lenguas Modernas (CR); } \\
\text { Revista Latinoamericana de Psicologia (CO) (x2); Rivista di Studi Italiani } \\
\text { (CA); Scholarship of Teaching and Learning Psychology (USA); Sexuality } \\
\text { Research and Social Policy (D); Studi di Italianistica nell’Africa australe } \\
\text { (ZA); Tenzone (ES); TESOL Quarterly (USA); The Journal of Clinical } \\
\text { Psychiatry (USA); The Modern Language Journal (USA); }\end{array}$ \\
\hline
\end{tabular}




\begin{tabular}{|c|l|}
\hline 1 & \multicolumn{1}{|c|}{2} \\
\hline Inne & $\begin{array}{l}\text { The Translator (UK); Training and Education in Professional Psychology } \\
\text { (USA); Transformative Works and Cultures (int); Verbum (FR); Wiener } \\
\text { Linguistische Gazette (AT); Word Literature Today (USA); Zeitschrift für } \\
\text { Slawistik (D) }\end{array}$ \\
\hline
\end{tabular}

Źródło: opracowanie własne.

Odniesienia do tekstów autorstwa polskich italianistów pojawiają się rzadko: w 13 artykułach odnajdziemy pojedyncze cytowania, z kolei 5 bibliografii końcowych przytacza dwie tego typu pozycje. Należałoby ponadto uczciwie zauważyć, że w dużej części są to odwołania uczniów do publikacji ich promotorów (co jest zrozumiałe, bo przecież akademickiej kultury uczymy się od naszych Mistrzów, a więc także z ich publikacji) lub do publikacji koleżanek i kolegów pracujących w tej samej jednostce (co jest równie zrozumiałe, bo twórczość ta jest nam z pewnością lepiej znana).

\section{Konkluzje}

Na podstawie ograniczonych danych trudno jest nakreślić wyraźny obraz dyscypliny. Bibliografia z roku 2019 ukazuje teksty polskich italianistów umiejscowione niejako na rozdrożu polskiej i włoskiej tradycji filologicznej: $\mathrm{z}$ jednej strony są to teksty pisane głównie w języku włoskim (zatem kierowane do odbiorcy włoskiego/włoskojęzycznego) i opierające się na włoskiej literaturze naukowej (zatem sięgające do tej właśnie tradycji akademickiej); z drugiej strony są to w większości publikacje krajowe, często lokalne (jeśli weźmiemy pod uwagę afiliację autora w stosunku do miejsca wydania tekstu czy afiliacji redaktora tomu, w którym tekst został opublikowany). Rzecz jasna, krajowe wydanie nie jest przeszkodą w międzynarodowej promocji dorobku naukowego, wszak dostęp do publikacji naukowych jest dziś ułatwiony dzięki licznym bazom naukowym ${ }^{23}$, bibliotekom cyfrowym ${ }^{24} \mathrm{i}$ - przede wszystkim - dzięki systemom publikacji open access. W przypadku tekstów wydanych lokalnie, bez możliwości wolnego dostępu, wciąż jednak istnieje ryzyko, że krąg odbiorców, do których tekst trafi, będzie bardzo ograniczony.

23 Np. Academia.edu i ResearchGate, na których swoje publikacje umieszcza również gros italianistów polskich.

24 Przykładem niech będzie amerykańska JSTOR czy europejska CEJSH (choć w zamyśle jest to baza danych gromadząca abstrakty, to dziś udostępnia również wiele artykułów w całości); powstało ponadto wiele polskich bibliotek cyfrowych. 
Przy wykazanej wyżej strukturze italianistycznych publikacji, w pewien sposób profilującej odbiorcę (prawdopodobnie najłatwiej będzie trafić do omawianych tekstów właśnie polskim italianistom), dziwić może niewielka ilość odniesień do prac rodzimej italianistyki, tj. do tradycji naukowej, w której nolens volens teksty te powstały. Wskazać można - jak sądzę - dwie hipotetyczne przyczyny tego stanu rzeczy: 1) rozproszenie zainteresowań badawczych i przynależność do odmiennych paradygmatów naukowych (por. mit schematu pojęciowego; Popper 1997; Bobrowski 2005); 2) nieznajomość bogatego dorobku polskiej italianistyki. Widzę też dwa rozwiązania tych problemów: 1) promocję międzyuczelnianych projektów naukowych (jak widzieliśmy, w praktyce współpraca autorska jest rzadka: tylko 9 pozycji w BIP19 napisanych zostało we współpracy, z czego tylko 3 teksty przez autorów afiliowanych przy różnych jednostkach naukowych; zob. Grochowska-Reiter i Słapek 2019 - UAM/UWr; Latos i Pronińska 2019 - SWPS/UP; Prola i Rosatti 2019a - UW/Uniwersytet Islandzki); taka współpraca przynosi też czysto praktyczne korzyści z punktu widzenia ewaluacji jakości działalności naukowej) ${ }^{25}$; 2) stworzenie pełnej bibliografii naukowej italianistyki polskiej, czemu po części służyć ma BIP19 (w przygotowaniu jest też bibliografia za lata wcześniejsze) ${ }^{26}$.

Tworzenie bibliografii naukowej ma nie tylko charakter kronikarski. Dla socjologii nauki - czy szerzej: metanauki - bibliografia jest podstawą do szczegółowej analizy bibliometrycznej, która pozwala na ukazanie działalności naukowej w określonym systemie relacji i procesów społecznych (w sensie społeczności naukowej, ale nie tylko). Oprócz analizy zawężonej do formalnej struktury publikacji naukowych (język, miejsce wydania, afiliacja, źródła bibliograficzne itp.), którą próbowałem zilustrować na poprzednich stronach, bibliometria dać może obraz dyscypliny w dużo szerszej skali, wykazując na przykład, czy zauważalne są $\mathrm{w}$ polskich badaniach italianistycznych wieloletnie projekty, kierunki tematyczne (a może modne chwilowo tematy; i jeśli tak, to jakie), czy zauważalna jest $\mathrm{w}$ danej dyscyplinie obecność autorytetów naukowych (których publikacje stosunkowo często pojawiają się w bibliografiach końcowych

25 Rozporządzenie MNiSW promuje artykuły pisane we współpracy międzyinstytucjonalnej, ponieważ wartość punktowa przyznana każdemu z autorów wynosi odpowiednio: 1) 100\% całkowitej wartości dla artykułów opublikowanych w czasopismach, którym przypisano 100, 140 i 200 pkt; 2) $\sqrt{ }(\mathrm{k} / \mathrm{m})$ dla artykułów opublikowanych w czasopismach o wartości 40 i 70 pkt; 3) k/m za artykuł, który ukazał się w czasopiśmie o wartości 20 pkt; gdzie $\mathrm{k}$ to liczba autorów pochodzących z ośrodka podlegającego ocenie, $m$ to całkowita liczba autorów tekstu (zob. Dz.U. 2019 poz. 392; \13).

26 Promocją dorobku polskiej italianistyki na arenie międzynarodowej są również artykuły recenzyjne. Warto, żeby tematem takich artykułów stały się prace polskich italianistów i żeby same recenzje ukazywały się w czasopismach zagranicznych. 
analizowanych tekstów), czy polityka ministerialna wpływa na rzeczywistą praktykę wydawniczą (i czy jest to polityka korzystna dla samych naukowców $)^{27}$ itp. Bardziej szczegółowa analiza dziedziny wymaga jednak odpowiednich (ilościowo i jakościowo) danych bibliograficznych, tj. pełnego zestawienia efektów naszej pracy naukowej.

Bibliometria ma także potencjał dydaktyczny: może być dobrym narzędziem w kształceniu młodej kadry naukowej, ponieważ opiera się na konkretnych danych empirycznych. Proste analizy bibliometryczne i odpowiednia interpretacja danych liczbowych mogą pomóc młodym adeptom filologii zrozumieć np. 1) pod wpływem jakich inspiracji powstaje dany tekst; 2) jacy autorzy mają największy wpływ na analizowane prace; 3) w jakim stopniu są to prace interdyscyplinarne; 4) jaki rodzaj badania został przeprowadzony, biorąc pod uwagę cytowania w tekście itp. (przy założeniu, że analizowana próba jest reprezentatywna; zob. Gile 2015: 245). Z pewnością analiza taka uświadomić może problemy związane $\mathrm{z}$ organizacją publikacji naukowych (jej związkiem z promocją badań i tzw. widocznością autora), a co za tym idzie wpłynąć może na bardziej świadomą indywidualną strategię wydawniczą oraz uważną budowę bibliografii końcowej własnych tekstów.

Na koniec zapożyczę raz jeszcze słowa Ewy Domańskiej promujące humanistykę performatywną (2017: 49) ${ }^{28}$ : ,chodzi tu nie tyle o krytykę istniejącego systemu, ile o konkretne eksperymenty w tworzeniu alternatyw dla systemu, który jest uważany (z różnych względów) za wadliwy, niesprawiedliwy; o praktykowanie konkretnych inicjatyw i pokazywanie w ten sposób, że zmiana jest możliwa”. Niech zatem przedstawiona tu analiza, a także sama Bibliografia, będą tego rodzaju inicjatywą w kontekście polskich badań italianistycznych; eksperymentem, który wpłynie na poprawę widoczności publikowanych tekstów (publikacje w dobrych czasopismach naukowych właściwych naszej dyscyplinie oraz promocja polskiej myśli naukowej przez koleżanki i kolegów italianistów), ale także na jakość naszych badań (rzetelne bibliografie, które są przecież podstawą każdego artykułu naukowego).

27 Przykładem niech będzie ministerialny wykaz wydawnictw publikujących recenzowane monografie naukowe, w którym obecność wydawnictw włoskich jest w zasadzie znikoma.

28 Wprawdzie rozważania autorki nie ograniczają się do działania w obrębie samej tylko nauki, ponieważ dotyczą „humanisty stojącego w obliczu realnych zagrożeń” (kryzysu demokracji, zmian klimatycznych itd.; ibid.), to jednak podobna humanistyka powinna charakteryzować również same środowisko naukowe. 


\section{Bibliografia}

Baccini, Alberto (2010). Valutare la ricerca scientifica. Uso e abuso degli indicatori bibliometrici, Bologna, il Mulino.

Biardzka, Elżbieta (2018). „Être chercheur en linguistique française en Pologne. Quelques remarques sur l'identité scientifique", Romanica Wratislaviensa, 65, s. 25-38.

Bobrowski, Ireneusz, 2005, O wspótistnieniu odmiennych dyskursów lingwistycznych, „Polonica”, 24-25, s. 5-19.

Domańska, Ewa (2017). Sprawiedliwość epistemiczna w humanistyce zaangażowanej, „Teksty Drugie", s. 41-59.

Drabek, Aneta (2012). Wykorzystanie bibliometrii w polityce naukowej, „Biuletyn EBIB” [on-line], 3(130), s. 1-7.

Gałkowski, Artur (2014). "L'insegnamento dell'italiano in Polonia: stato attuale, motivazioni, percezione, difficoltà, tipologia degli studenti”, [w] Anna Kucharska (red.), Nauczanie i uczenie się języka hiszpańskiego i wtoskiego, Lublin, Werset, s. 9-21.

Gile, Daniel (2015). Analyzing Translation studies with scientometric data: from CIRIN to citation analysis, „Perspectives: Studies in Tranlatology”, 23(2), s. 240-248.

GUS = Gówny Urząd Startystyczny (1999). Definicje pojęć z zakresu statystyki, nauki i techniki, Warszawa, GUS, Departament Produkcji i Usług. Dostępny on line: https://stat.gov.pl/ metainformacje/slownik-pojec/pojecia-stosowane-w-statystyce-publicznej/15,pojecie.html.

Hood, William W., i Wilson, Concepción S. (2001). The literature of bibliometrics, scientometrics, and informetrics, „Scientometrics”, 52/2, s. 291-314.

Ivanovska-Naskova, Ruska (2019). Gli studi contrastivi dell'italianistica macedone: sviluppi e recenti prospettive, „Italica Wratislaviensia”, 10(1), s. 59-76.

Jamrozik, Elżbieta (2014). Zarys historii nauczania języka włoskiego w Polsce, "Języki obce w szkole”, 3, s. 23-30.

Kaliska, Marta (2018). Model uczenia języków obcych w szkole wyższej na przykładzie języka włoskiego: Założenia teoretyczne, metodologia nauczania i zintegrowany rozwój kompetencji, Warszawa, Wydawnictwo Naukowe Instytutu Komunikacji Specjalistycznej i Interkulturowej, Uniwersytet Warszawski.

Korzen, Iørn (red.). (2018). Studi Italiani di Linguistica Teorica e Applicata, No. 1/2018, Vol. XLVII: „La linguistica italiana nei Paesi nordici”, Pisa, Pacini Editore.

Martínez-Gómez, Aída (2015). Bibliometrics as a tool to map uncharted territory: A study on non-professional interpreting, „Perspectives: Studies in Tranlatology”, 23(2), s. 205-222.

Palmarini, Luca (2015). „Gli albori dell'insegnamento della lingua italiana presso l'Università Jagellonica di Cracovia”, [in] Anna Klimkiewicz, Maria Malinowska, Alicja Paleta i Magdalena Wrana (red.), L'Italia e la cultura europea, Firenze, Franco Cesati, s. 29-37.

Popper, Karl Raimund (1997). Mit schematu pojęciowego. W obronie nauki i racjonalności, Warszawa, Książka i Wiedza.

Stefaniak, Barbara (1998). „Badania bibliometryczne, informetryczne, naukometryczne”, [in] Eugeniusz Ścibor (red.), Informacja naukowa w Polsce: tradycja i nowoczesność, Olsztyn, Wydawnictwo WSP, s. 197-220.

Van Raan, Anthony F.J. (2003). The use of bibliometric analysis in research performance assessment and monitoring of interdisciplinary scientific developments, „Technikfolgenabschätzung - Theorie und Praxis", 12/1, s. 20-29. 
Widłak, Stanisław (1991). "Insegnamento dell'italiano in Polonia. Approccio storico", [in] Ignazio Baldelli i Bianca Maria Da Rif (red.), Lingua e letteratura italiana nel mondo oggi. Atti del XIII Congresso dell'Associazione internazionale per gli studi di lingua e letteratura italiana (Perugia, 30 maggio - 3 giugno 1988), Firenze, Olschki, s. 703-709.

Widłak, Stanisław (2015). "Dalla preistoria e dalla storia degli studi italiani a Cracovia", [in] Anna Klimkiewicz, Maria Malinowska, Alicja Paleta i Magdalena Wrana (red.), L'Italia e la cultura europea, Firenze, Franco Cesati, s. 17-28.

Żaboklicki, Krzysztof (2012). “Un po’ di storia e qualche ricordo personale”, [w] Hanna Serkowska (red.), Italianistica ieri e oggi: trentesimo anniversario del Dipartimento di Italianistica all'Università di Varsavia, Warszawa, Wydawnictwo Naukowe Semper, s. 10-13.

Żylicz, Maciej (2020, 3 lutego). Uwagi Zespołu ds. monitorowania wdrażania reformy szkolnictwa wyższego i nauki dotyczace statutów uczelni i oceny indywidualnej nauczycieli akademickich, Warszawa, MNiSW. Dostęp online: https://www.gov.pl/web/nauka/zespol-do-spraw -monitorowania-wdrazania-reformy-szkolnictwa-wyzszego-i-nauki.

\section{Korpus}

Słapek, Daniel (red.). (2020). Bibliografia dell'italianistica polacca del 2019, „Italica Wratislaviensia”, 11/1, s. 253-274.

\section{Elementy korpusu przytoczone w tekście}

Baldacci, Alessandro, Porczyk, Anna i Skocki, Tomasz (red.). (2019). Nuova corrente. Rivista di letteratura e filosofia, n 163: „Il futuro della fine. Narrazioni e rappresentazioni dell'apocalisse dal Novecento a oggi”, Novara, Interlinea [konferencja „Il futuro della fine. Narrazioni e rappresentazioni dell'apocalisse dal Novecento a oggi”, 4-5.12.2017, Uniwersytet Warszawski, Katedra Italianistyki].

Balducci, Marino Alberto (red.). (2019). Intersezioni dantesche 2016/2018. Ricerche ermeneutiche per il programma universitario "Conoscersi per ritrovarsi" del Soroptimist International d'Italia Club Pistoia-Montecatini Terme \& Carla Rossi Academy International Institute of Italian Studies, Pistoia, Carla Rossi Academy Press [seminarium „Ermeneutica Dantesca”, 2016 i 2018 r., Carla Rossi Academy, Pistoia].

Della Corte, Federico, Masi, Leonardo i Ślarzyńska, Małgorzata (red.). (2019). Il secolo di Franco Fortini. Studi nel centenario della nascita, Roma, Artemide [konferencja "Il secolo Di Franco Fortini. Conversazioni nel centenario della nascita”, 19-20.05.2017, Uniwersytet Kardynała Stefana Wyszyńskiego w Warszawie].

Gałkowski, Artur (2019a). Development of International Works on Onomastic Terminology: Review of Slavic Approaches, „Annales Universitatis Mariae Curie-Skłodowska, section FF - Philologiae", 37/1, s. 61-81.

Gałkowski, Artur (2019b). [recenzja czasopisma:] Rivista Italiana di Onomastica RION, vol. XXIV, Anno XXIV, no 1-2, primo - secondo semestre 2018, s. 1190, direttore Enzo Caffarelli, „, Onomastica”, 69, ss. 333-336.

Grochowska-Reiter, Anna i Słapek, Daniel (2019). Discordanze teorico-pratiche nella presentazione di alcune norme grammaticali al livello A1/A2 nelle grammatiche di italiano LS/L2, „Italica Belgradensia”, s. 7-24. 
Gurgul, Monika, Surma-Gawłowska, Monika i Megale Teresa (red.). (2019). Italica Wratislaviensa, 10/2: „Donne del/nel teatro italiano: nodi storici, pratiche d'arte e di vita”, Toruń, Wydawnictwo Adam Marszałek [konferencja „Donne del/nel teatro italiano: nodi storici, pratiche d'arte e di vita”, 16-17.11.2018, Uniwersytet Jagielloński].

Ivanovska-Naskova, Ruska i Słapek, Daniel (red.). (2019). Italica Wratislaviensa, 10/1: „Italiano e lingue slave: problemi di grammatica contrastiva konferencja”, Toruń, Wydawnictwo Adam Marszałek [konferencja „Italiano e lingue slave: problemi di grammatica contrastiva", 30.11-1.12.2018, Uniwersytet Wrocławski].

Jamrozik, Elżbieta i Prola, Dario (red.). (2019). Kwartalnik Neofilologiczny, 66/2, Warszawa, Wydział I Nauk Humanistycznych i Społecznych PAN [konferencja „Dal monologo al polilogo: l'Italia nel mondo. Lingue, letterature e culture in contatto", 6-8.04.2017, Uniwersytet Warszawski, IKSI].

Latos, Agnieszka i Pronińska, Aleksandra (2019). Il sistema nominale italiano e polacco a confronto: riflessioni sulle categorie grammaticali di genere e caso, „Italica Wratislaviensia”, 10/1, ss. 111-131.

Maślanka-Soro, Maria we spółpracy z Pifko-Wadowska, Anna (red.). (2019). "Vedi lo sol chén fronte ti riluce". La vista e gli altri sensi in Dante e nella ricezione artistico-letteraria delle sue opere, Canterano, Aracne [konferencja Northern European Dante Network "Vedi lo sol che ' $n$ fronte ti riluce. La vista e gli altri sensi in Dantee nella ricezione artistico-letteraria delle sue opere", 19-21.04.2017, Uniwersytet Jagielloński w Krakowie].

Miszalska, Jagwiga (2019). [recenzja książki] Apologia kobiecego ducha. Sibilla Aleramo i jej związki z polska, Anita Kłos, Lublin, UMCS, „La Rassegna della letteratura italiana”, s. 515-516.

Miziołek, Jerzy we współpracy z Cincotta, Roberto i Rejmak, Barbara (red.). (2019). Italia e Polonia (1919-2019). Un meraviglioso viaggio insieme lungo cento anni / Wtochy i Polska (1919-2019). Sto lat wspólnej fascynującej podróży, Warszawa, Wydawnictwa Uniwersytetu Warszawskiego.

Porczyk, Anna (2019). Erri De Luca e la Bibbia. Un autore formatosi sulle Sacre Scritture, Napoli, Dante \& Descartes.

Prola, Dario i Rosatti, Stefano (2019a). "Un'Italia storico-letteraria fra nazionalismi e transnazionalità", [in] Dario Prola, Stefano Rosatti (red.), Sponde, confini, trincee: l'Italia nell'Europa post-1918, Warszawa, DiG, s. 9-14.

Prola, Dario i Rosatti, Stefano (red.). (2019b). Sponde, confini, trincee: l'Italia nell'Europa post1918, Warszawa, DiG [konferencja „Sponde, confini, trincee: l'Italia nell'Europa post 1918”, 7-8.06.2018, Uniwersytet Islandzki].

Rella, Angelo, Sánchez, Jorge Diego i Cerrato, Daniele (red.). (2019). Querelle des Femmes: Thoughts, Voices and Actions, Sevilla, Benilde [konferencja „Voces masculinas y voces femeninas en la querelle des femmes en Italia y Europa”, 12.11.2018, Uniwersytet w Sewilli].

Sosnowski, Roman (2019). "L'italiano dell'economia in diacronia: l'inquadramento della lingua dell'economia preilluministica e i contatti con altre lingue", [in] Jacqueline Visconti (red.), Parole nostre. Le diverse voci dell'italiano specialistico e settoriale, Bologna, il Mulino, s. 141-150. 
Tylusińska-Kowalska, Anna, Lipszyc, Dominika i Cilloni-Gaździńska, Giulia (red). (2019). Altre. Il doppio e le alterità femminili nella cultura italiana ed europea, Warszawa, Instytut Komunikacji Specjalistycznej i Interkulturowej, Uniwersytet Warszawski. [konferencja „Altre. Il doppio e le alterità femminili nella cultura italiana ed europea”, 19-20.04.2018, Uniwersytet Warszawski, IKSI].

Wojtkowska-Maksymik, Marta (red.). (2019). L'epica cavalleresca dell'età moderna: un modello europeo. Atti del convegno, Roma, 20-21 settembre 2018, Roma, Accademia Polacca delle Scienze. 